\title{
Binderholz prevzel BSW Timber
}

Špela Ščap, Gozdarski inštitut Slovenije, Oddelek za gozdno tehniko in ekonomiko

Objavljeno na spletu 14.01.2022 (https://doi.org/10.20315/IG.2022.0005)

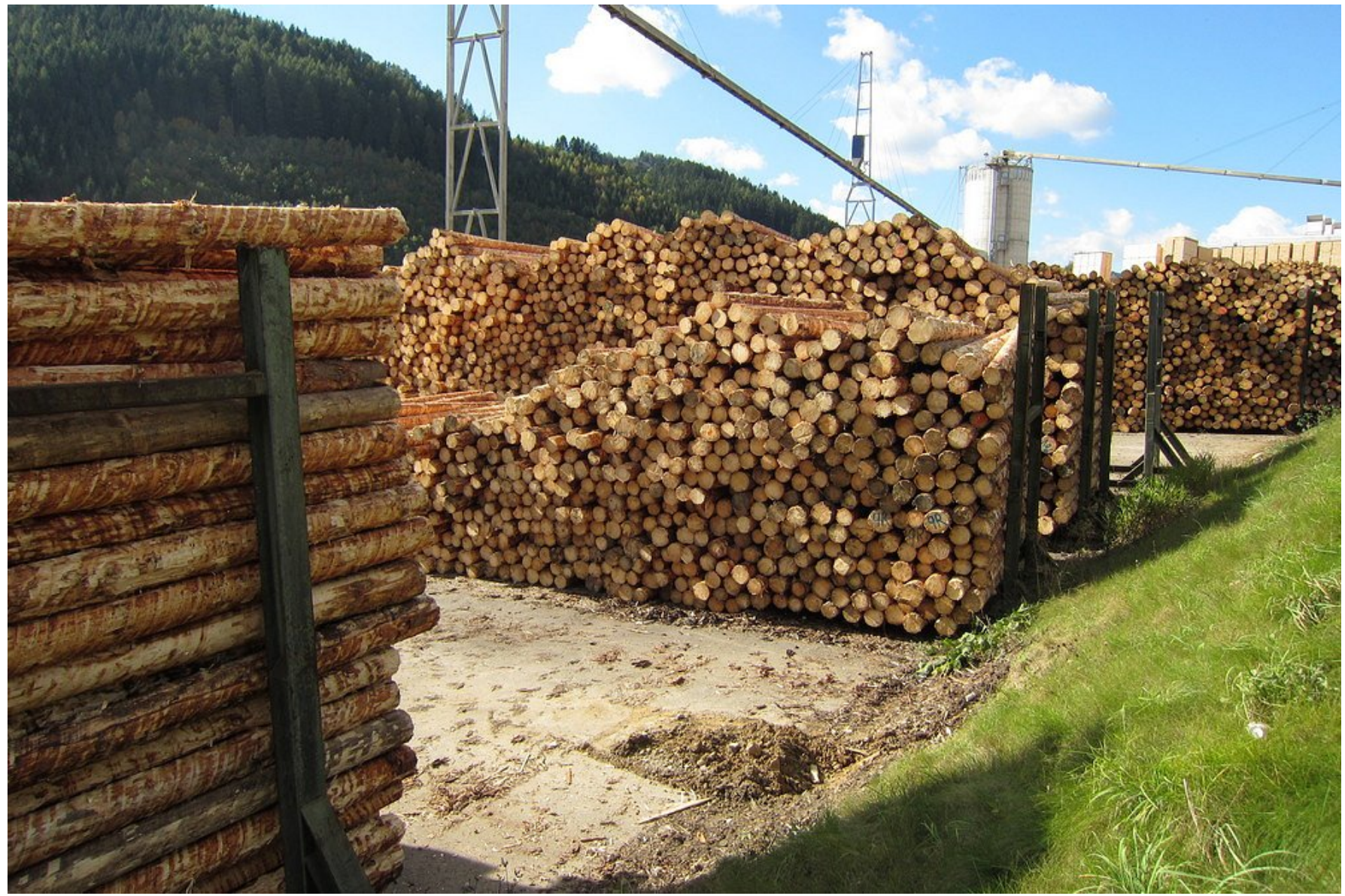

Nedavno je avstrijsko podjetje Binderholz GmbH prevzelo britansko podjetje BSW Timber Ltd $\mathrm{s}$ sedežem v Earlstonu na Škotskem. Tako bo podjetje Binderholz v letošnjem letu s skupnim letnim prometom v višini 2,6 milijarde evrov in približno 5.000 zaposlenimi postal največji evropski koncern $\mathrm{s}$ področja žagarske industrije in industrije masivnega pohištva.

Blagovna znamka BSW se bo po združitvi s koncernom Binderholz obdržala, podjetje pa bo še naprej vodilo sedanje vodstvo. Prevzem BSW Timber bo podjetju Binderholz GmbH omogočal razširitev proizvodnih dejavnosti tudi v Združeno kraljestvo, ki je v zadnjem obdobju eden izmed hitro rastočih trgov lesnih izdelkov in lesene gradnje $v$ svetu. Binderholz in BSW načrtujeta obsežen investicijski 
program za tovarne, med drugim povečanje zmogljivosti obratov, doseganje največje možne neto proizvodnje ter povečanje ponudbe različnih vrst lesnih izdelkov. Kot ena osrednja/glavna bodoča investicija koncerna bo vzpostavitev obratov za izdelavo križno lepljenih plošč (CLT).

Naj spomnimo, da je škotsko podjetje BSW Timber leta 2018 načrtovalo vzpostavitev žagarskega obrata na Gomilskem, s proizvodno zmogljivostjo 300.000 m3 predelane hlodovine na leto. Zaradi zapletov do gradnje ni prišlo. Proti koncu lanskega leta so mediji pisali o novih načrtih podjetja BSW Timber in sicer o morebitni investiciji v lesnopredelovalni center z bistveno višjo stopnjo dodane vrednosti (poleg žage naj bi zgradili tudi obrat za proizvodnjo križno lepljenih plošč in drugih proizvodov) in sicer na dveh drugih možnih lokacijah v Sloveniji. Tuji mediji pa so proti koncu lanskega leta zapisali, da zaenkrat še ni jasno, ali Binderholz (in BSW) načrtuje obnovo investicijskih načrtov gradnje lesnopredelovalnega centra v Sloveniji. 